\title{
Global Seroprevalence of West Nile Virus in Horses of Morocco
}

\author{
Ghizlane Hanafi Houoiten ${ }^{1}$, Ikhlass El Berbri ${ }^{1 *}$, Wissal Mahir ${ }^{1}$, Kaoutar Aalilouch ${ }^{1}$, Badaoui Bouabid ${ }^{2}$, Stephan \\ Zientara $^{3}$, Hassan Alyakine ${ }^{4}$, Mehdi El Harrak ${ }^{5}$, and Ouafaa Fassi Fihri ${ }^{1}$ \\ ${ }^{I}$ Department of Pathology and Veterinary Public Health, Agronomic and Veterinary Institute Hassan II, BP: 6202, Rabat-Instituts, Rabat, Morocco \\ ${ }^{2}$ Department of Biology, Mohammed V University, Faculty of Sciences, BP: 1014 RP, Rabat, Morocco \\ ${ }^{3}$ ANSES, Maisons-Alfort Laboratory for Animal Health, 94700, Paris, France \\ ${ }^{4}$ Department of Medicine, Surgery and Reproduction, Agronomic and Veterinary Institute Hassan II, BP: 6202, Rabat-Instituts, Rabat, Morocco \\ ${ }^{5}$ Department of Research and Development, Multi-Chemical Industry Santé Animale, Box 278, Mohammadia 28810, Morocco \\ * Corresponding author's E-mail: i.elberbri@iav.ac.ma; (D) ORCiD: 0000-0002-0121-6861
}

\begin{abstract}
West Nile Fever (WNF) is a viral emerging mosquito-borne disease causing mortality and morbidity with varying severity (from mild fever to severe neuroinvasive disease) among human and animal populations in many parts of the world. The current study aimed to confirm the virus circulation and assess the disease seroprevalence in horses of Morocco. A sample of 1171 healthy non-vaccinated (against-WNF) horses, taken from 11 (out of 12) regions of the country during July-December 2016, was primarily tested using competitive ELISA assay (cELISA). All cELISA-reactive positive and doubtful sera $(n=269)$ were further tested by virus neutralization test $(V N T)$. The results of cELISA test revealed an overall WNF seroprevalence in $21.8 \%$ (255/1171) of sampled horses. This rate decreased to $18.8 \%$ $(220 / 1171)$ after the confirmation of VNT. The WNF seroprevalence in the current study varied significantly by age, gender, and breed of the tested horses. Indeed, the higher seropositivity rates were found in the oldest $(27.7 \%)$, female $(22.0 \%)$, and saddle $(32.1 \%)$ horses. However, the origin of animals did not show any significant effect on the West Nile virus infection. The obtained results of the present study, therefore, provided serological and epidemiological evidence of the endemicity of the WNV in horse populations of Morocco.
\end{abstract}

Keywords: Emerging disease, Morocco, Mosquito-borne disease, Seroprevalence, West Nile virus.

\section{INTRODUCTION}

West Nile fever (WNF) is an emerging zoonotic mosquito-borne disease caused by a single-stranded RNA virus of the Flaviviridae family (Campbell et al., 2002). It circulates in a natural transmission cycle involving birds, the virus natural primary host (over 250 species), Ornithophilic Culex ssp (mosquito vectors), as well as incidental hosts (i.e., horses and humans) that are generally dead-end hosts as their viremia level is not enough to spread the disease (Beasley et al., 2005; Reiter, 2010; OIE, 2021). West Nile Fever is a notifiable disease listed in the Terrestrial Animal Health Code of the Organisation for Animal Health (OIE).

The symptoms of West Nile infection vary in severity, from a mild fever to severe and fatal neuroinvasive disease in various host species (Nall, 2018; Habarugira et al., 2020). However, the neurological form remains the most serious complication of the disease (Samuel and Diamond, 2006). Although the disease remains asymptomatic in most infected people (8 out of 10), West Nile virus (WNV) infection has been associated with severe meningoencephalitis and acute flaccid paralysis in some infected people (CDC, 2018). In animals, WNV can cause fatal infection in birds (especially corvids), alligators, and horses as well as other domestic and wild mammals, such as cattle, sheep, cats, dogs, skunks, and rodents (McLean et al., 2002; Bauerfeind et al., 2016; OIE, 2021).

Since its first isolation in 1937 in the West Nile district of Uganda from a febrile woman, the WNV has been reported over a broad geographical range, including Africa, parts of Europe, the Middle East, West Asia, and Australia, as well as North, Central, and South America (Beasley et al., 2005; Murray et al., 2010; WHO, 2017; Habarugira et al., 2020). Outbreak sites are usually on major migratory routes of birds. Indeed, the most important outbreaks occurred in Greece, Palestine, Romania, Russia, France, and the USA (WHO, 2017; OIE, 2021).

In Morocco, according to the official declaration provided by the National Veterinary Services, the WNF disease appeared for the first time in 1996, when an outbreak caused the deaths of 42 horses (out of 94 cases) and 1 human (Tber, 1996; Figuerola et al., 2009). Afterwards, in 2003, the disease reappeared in nine horses (Schuffenecker et al., 
2005). Then, after a silence of seven years (in 2010), the disease reappeared when WNF was confirmed in 17 horses. Since then, there has been no declaration of clinical cases of the disease in the country. However, five seroepidemiological studies carried out in the north of the country revealed the circulation of the WNV in $4.0 \%$ of 346 native wild birds (Figuerola et al., 2009), 11.8\% of 499 healthy people (El Rhaffouli et al., 2012), 31\% of 840 (Benjelloun et al., 2017) and 33.7\% of 92 (Assaid et al., 2020) horses, as well as $60 \%$ and $62 \%$ of military working animals (49 horses and 231 dogs, respectively, Durand et al., 2016). Likewise, an entomological study confirmed the virus circulation among the culex mosquito populations in the country (Assaid et al., 2020). However, all these studies were carried out only in the north of Morocco. Therefore, to confirm the virus circulation and to assess the national seroprevalence of the disease throughout the country, the present study was conducted in 11 (out of 12) regions of Morocco, targeting a large sample of 1171 horses.

\section{MATERIAL AND METHODS}

\section{Ethical consideration}

The samples were collected by a qualified veterinarian and a veterinary technician. The horse breeders were always informed of the objectives and the nature of the analysis.

\section{Study area and sampling}

The study was carried out across the country of Morocco in 11 administrative regions (out of 12). The reason for having no sample from the Draa-Tafilalet region (region number " 8 ") was the small horse population in this region (Figure 3). The investigations were conducted from July to December 2016. This cross-sectional study involved a sample of 1171 horses, which represents $1 \%$ of the total population of Morocco estimated at 110000 horses (Chemsi, 20019). All the tested animals were healthy, non-vaccinated (against WNV), and with no clinical signs of WNF disease. The horse farms, as well as the tested animals, were chosen randomly. The horses were born, bred, and lived for at least all the previous year within their horse farm.

\section{Samples pre-processing}

The blood samples of horses were drawn from the jugular vein in $5 \mathrm{ml}$ sterile dry tubes and then sent to the laboratory for testing at a temperature of $+4^{\circ} \mathrm{C}$. After centrifugation (20 minutes at $2500 \mathrm{RPM}$ ) and serum collection, samples were stored at $-20^{\circ} \mathrm{C}$ (Assaid et al., 2020).

\section{Enzyme-Linked Immunosorbent Assay (ELISA) Competitive}

All the 1171 horse sera were tested for the presence of WNV antibodies using the ID Screen ${ }^{\circledR}$ West Nile Competition Multi-species Kit (ID.Vet, France), for the detection of the monoclonal antibody to WNV envelope protein (pr-E) by the competitive ELISA method (following the manufacturer's instructions). The absorbance (optical density) of the ELISA test results was read at a wavelength of $450 \mathrm{~nm}$. To confirm the ELISA test results, all the positive and dubious samples were re-tested by the serum virus neutralization test.

\section{Serum virus neutralization test}

The serum virus neutralization (SVN) test was preceded by the multiplication and then the titration of the virus steps. The used WNV strain "Mor.1996 EQ" had been initially isolated in 1996 from the brain of a mare originating from the first outbreak in Morocco (El Harrack et al., 1997). It had been isolated on BSR cells (BHK cell clone: Baby Hamster Kidney cells) and was then adapted on Vero cells (continuous lineage African green monkey kidney cells). For the virus multiplication in cell culture, within this study, the same cell lineage (VERO cells) was used (OIE, 2018).

Virus titration was conducted on $96-$ well Nunc plates seeded by Vero cells at $120,000 \mathrm{cells} / \mathrm{ml}$. This titration was performed according to, first three serial 10-fold dilutions up to $10^{-3}$ and then, to five serial 4-fold dilutions (1/4) up to $10^{-6}$. The titration was calculated according to the Reed and Muench method, based on the observation of the cytopathogenic effect on Vero cells after 9 days of incubation at $37^{\circ} \mathrm{C}, 5 \% \mathrm{CO}_{2}$, the obtained virus titer was $10^{4}$ $\mathrm{DITC}_{50} / \mathrm{ml}$ (Ramakrishnan, 2016; Reed and Muench,1938). The SVN test was performed following the OIE "Manual of Diagnostic Tests and Vaccines for Terrestrial Animals" (OIE, 2018). The cytopathogenic effect was observed from 5 to 9 days after incubation.

\section{Data and statistical analysis}

The data were analyzed according to four factors, including age, gender, region of origin, and breed of the horses. The different breeds were grouped into five classes according to their typical discipline, including Arabian (race and show horses), Barb and Arabian-Barb (BA-AB for Tbourida (Moroccan ancient equestrian art) and breeding competition), Thoroughbred and Anglo-Arabian (TB-AA) (racehorses), Saddle horses (SH) (mainly used for show 
jumping), and Pony (used for short rides). The proportions of seroprevalences according to the four factors listed above were compared by calculating $95 \%$ confidence intervals with the Mantel-Haenszel Chi-Square test in OpenEpi@ Software (2021).

\section{RESULTS}

The competitive ELISA test results for the 1171 horse sera revealed that $255(21.8 \%)$ were positive for WNV antibodies, and $14(1.2 \%)$ were dubious. As previously stated, all positive and doubtful sera were re-tested with the SVN. Out of the 269 re-tested sera (255 positive and 14 doubtful), 220 were positive in both tests yielding a national WNF seroprevalence of $18.8 \%$.

This seroprevalence varied significantly $(\mathrm{p}<0.05)$ according to the age, gender, and breed factors of tested animals. Indeed, the oldest animals showed higher seropositivity $(27.7 \%)$ than the younger ones (13.9\%, Figure 1). Females were more frequently seropositive $(22.0 \%)$ than males $(17.2 \%)$. Moreover, the SH breeds showed the highest seropositivity $(32.1 \%)$, while the TB-AA breeds showed the lowest one (14.7\%, Figure 2). The seroprevalence variation according to the three factors (age, gender, and breed) was highly significant, as the results of the Chi-squared test were respectively $\chi^{2}=18.4(\mathrm{p}<0.05), \chi^{2}=8.9(\mathrm{p}<0.05)$, and $\chi^{2}=15.2(\mathrm{p}<0.05)$. However, the area of origin of animals has shown no effect on the WNV infection $\left(\chi^{2}=13.1, \mathrm{p}>0.05\right.$, Figure 3$)$.

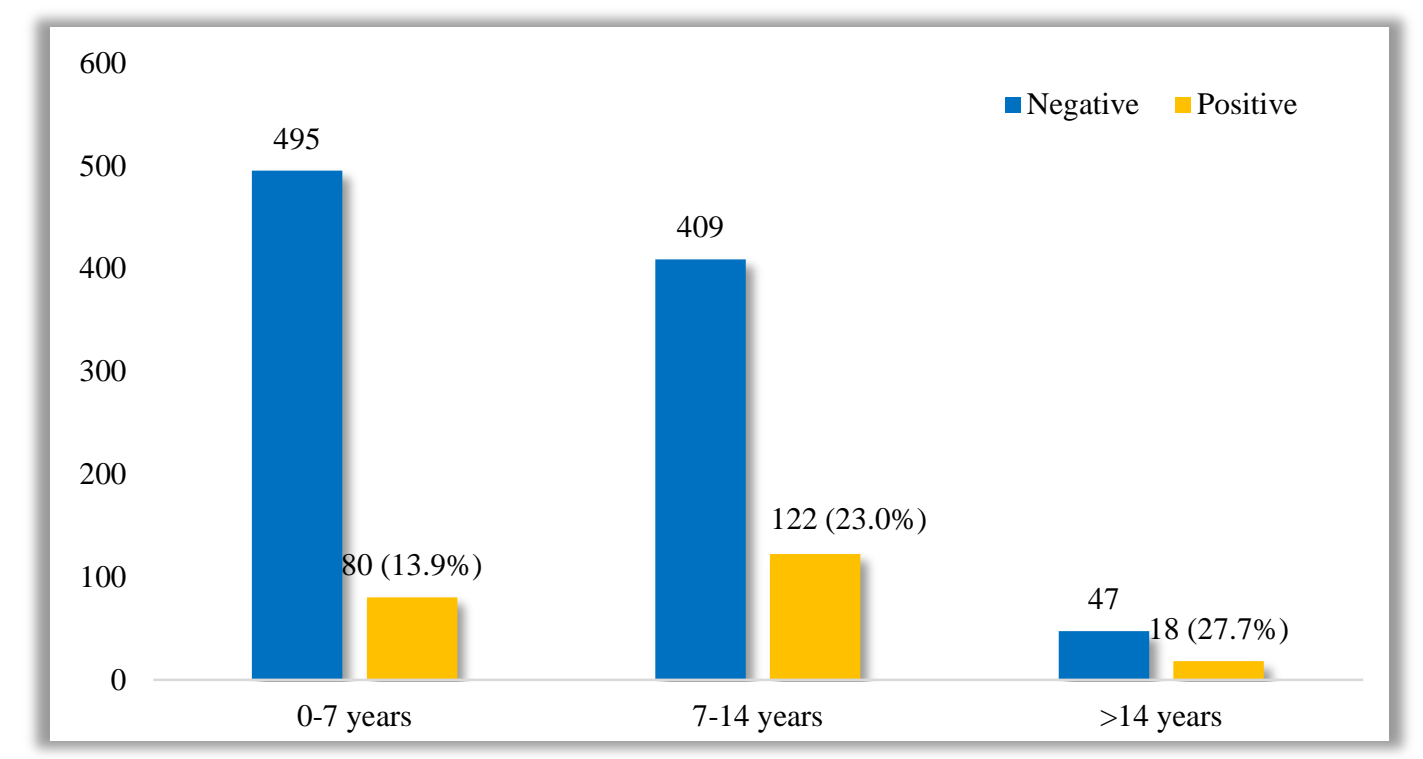

Figure 1. West Nile Virus seroprevalence variation by age of tested horses during July-December 2016 in Morocco

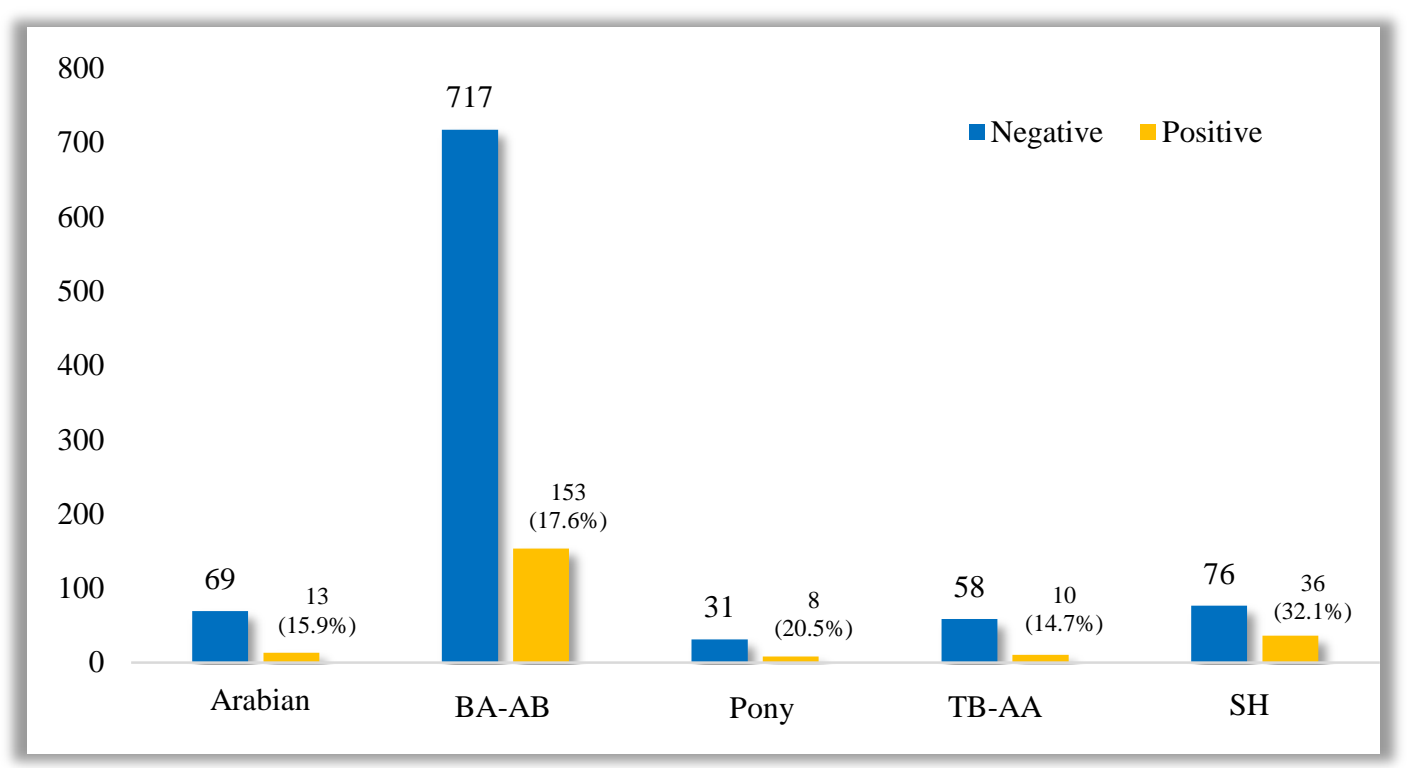

Figure 2. West Nile Virus seroprevalence variation by horse breeds (Arabian, BA-AB, Pony, TB-AA, and SH) during July-December 2016 in Morocco 


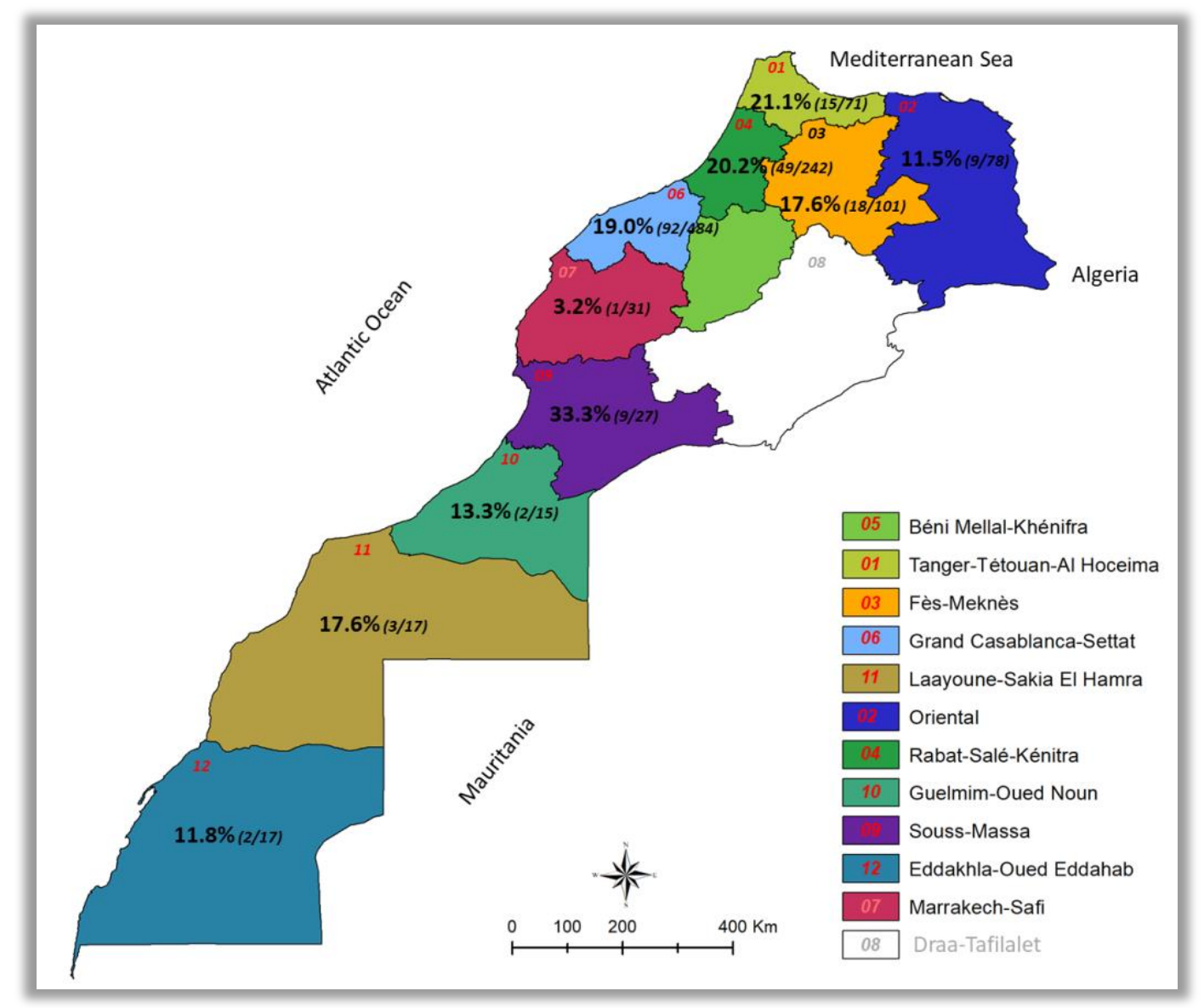

Figure 3. West Nile Virus seroprevalences in horses during July-December 2016 in different regions of Morocco

\section{DISCUSSION}

West Nile fever is a zoonotic mosquito-borne disease that can cause fatal neurological diseases in humans as well as various domestic and wild animal species, especially horses and birds. The present study provides serological evidence of the WNV circulation among horse populations all over the country of Morocco, with a global seroprevalence of $18.8 \%$. The current study is the first to report evidence of WNV circulation in the south of Morocco, as all the previous Moroccan studies (Durand et al., 2016; Benjelloun et al., 2017; Assaid et al., 2020) were conducted only in the north of the country. In Morocco, as in other countries of the Mediterranean basin, the disease causes sporadic outbreaks in humans and animals. At first, this latter observation had led to the hypothesis that the virus was absent from this area (i.e., Mediterranean basin) and could have been periodically brought and seeded in it by infected migratory birds (Figuerola et al., 2009). However, previous studies, along with the current study, have provided serological evidence of the virus circulation in different species in Morocco, including humans, horses, dogs, and even native birds (virus natural reservoir), as well as viral evidence of the virus circulation among the Culex mosquito populations. This serological and viral evidence, along with the lack of clinical cases declared in the country since the last outbreak of the disease in 2010 , strongly suggest that the virus is circulating undetected in the country. This latter observation confirms the observation reported by Figuerola et al. (2009). Indeed, in their study conducted after the two first outbreaks in the country (in 1996 and 2003), they suggested that the virus circulation in Morocco may be back then already undetected as it was the case at that moment in southern Europe. Silent circulation of the virus was also reported in different countries within the Mediterranean area such as Spain, the Czech Republic, and Italy, as well as other areas in Europe (Calzolari et al., 2010) and South America (Fujita et al., 2018). As reported by Figuerola et al. (2009), the silent circulation of WNV in one area, suggests that the ecological and epidemiological factors leading to disease outbreaks are not quite clear. Furthermore, the current study indicated that the WNV seroprevalence significantly increased with the age of tested animals. This means that the risk of animals being infected by WNV has increased over time and animals have been regularly infected by the virus. Indeed, as reported by Autorino et al. (2002), when the seroprevalence increases with the age of animals, it means that the animals have had more chances of being infected by the virus over time. This implies that the virus is regularly circulating in the area where the animals are from. This epidemiological observation, along with the serological and viral evidence (particularly in native birds) previously mentioned, and the fact that the infection occurs throughout the country, with no significant difference between the different regions, demonstrate that the WNV infection is not sporadic or periodically introduced, but is an endemic disease in Morocco. 
The WNV seroprevalence rate of $18.8 \%$ found in horses in the current study has been the lowest in Morocco so far. The other Moroccan studies have found seroprevalence rates ranging from 31.0 to 62.0\% (Durand et al., 2016; Benjelloun et al., 2017; Assaid et al., 2020). However, in these studies, the sample of tested animals included nonvaccinated as well as vaccinated horses against the WNV, while the present study was based only on non-vaccinated animals. This may explain the higher seroprevalence rates observed in these studies compared to those of the current study. These high rates may also be explained by the fact that the other studies had been undertaken as mentioned above, only within the northern part of the country (close or even within the declared outbreak areas), whilst the present study's samples were collected from animals from different areas across the country (within and out of the declared outbreak areas). The rate in the current study was also lower than those reported in other parts of the Mediterranean basin, such as the northeastern part of Algeria, where 26.8\% (19/293) of healthy and unvaccinated horses were found seropositive for WNF in 2014 (Lafri et al., 2017). Moreover, in five major regions of Jordan, 24.9\% (63/253) of surveyed horses were seropositive for WNV (Abutarbush, 2014), and in Western Spain, 19.72\% (143/725) of horses were confirmed as positive for WNV (Guerrero-Carvajal et al., 2020). However, the rate in the current study was higher than others reported in the Mediterranean area, such as south-western Tunisia, where 4 (14.3\%) of 28 tested horses were seropositive (Ben Hassine et al., 2014), the Balearic Islands, where 6.4\% (11/172) of horses were detected with antibodies against WNV (Vanhomwegen et al., 2017), and Southern France, where WNV antibodies were found in 291 (9.7\%) of 2995 tested horses (Durand et al., 2002).

Furthermore, in the current study, the seroprevalence varied significantly by gender, breed/discipline, and age of horses. Indeed, according to the results of the present study, age appeared to be a major risk factor for the WNV infection, as the seroprevalence rates increased significantly with age in a highly significant way $(\mathrm{p}<0.0001)$. Other studies have also reported that the risk of WNV infection increased with the age of animals (Ben Hassine et al., 2014; Cardinale et al., 2017; Guerrero-Carvajal et al., 2020). However, others reported that age was not associated with an increased risk of being seropositive for WNV (García-Bocanegra et al., 2012; Abutarbush, 2014; Vanhomwegen et al., 2017). In fact, as reported by Autorino et al. (2002) and stated above, when no significant differences in age-specific prevalence are observed in one area, it indicates that the horse populations have not been exposed in the previous years to WNV, which means that these animals are not regularly infected by the virus, as they would have been in an endemic area. The WNV seroprevalence variation regarding the gender of horses was reported by many studies. However, most of them, unlike the current study, have found either a higher incidence of WNV in male horses than females (Ostlund et al., 2001; Abutarbush, 2014; Baba et al., 2014) or no effect of gender on seropositivity (Durand et al., 2002; Hassine et al., 2014; Bażanów et al., 2018; Ben Guerrero-Carvajal et al., 2020). Indeed, to date, the effect of gender on the susceptibility to WNV infection is still unknown. Likewise, a recent study has reported that WNV seropositivity among equids was not significantly associated with body score, type of housing, aptitude, competition, and size of herd (Guerrero-Carvajal et al., 2020). Therefore, although the seroprevalence was significantly associated with the breed/discipline factor in the present study, there has been no tangible evidence that may explain the reason for the effect of this factor on WNV risk of infection. Indeed, as reported by different studies, the WNV risk of infection must be examined in terms of many different factors (strain characteristic, ecologic and environmental conditions, and vector behavior) that intertwine and change over different scales of time and space (Figuerola et al., 2009; Lockaby et al., 2016).

\section{CONCLUSION}

Given the findings of the present study, it has been concluded that the West Nile disease is endemic throughout the country of Morocco, with a global seroprevalence of $18.8 \%$ among the horse populations. However, the exact ecological and epidemiological factors leading to disease outbreaks remain unknown in the country. Indeed, despite a significant association found in this study between the disease's seroprevalence and age, gender, and breed/discipline of horses, the influence of these factors (especially the two latter ones) on the risk of infection by the WNV remains unknown. Further investigations to understand the complex interaction of the effects of the different factors associated with WNV incidence are therefore necessary.

\section{DECLARATIONS}

\section{Conflicts of interest}

The authors have no conflicts of interest to declare.

\section{Authors' contributions}

Ghizlane Hanafi Houoiten, Ouafae Fassi Fihri, Mehdi El Harrak and Hassan Alyakine designed and coordinated the work. Ghizlane Hanafi Houoiten collected the samples from the field with the contribution of Wissal Mahir and Ikhlass 
El Berbri. Ghizlane Hanafi Houoiten performed the laboratory analyses with the contribution of Wissal Mahir, Kaoutar Aalilouch, and Stephan Zientara. Ghizlane Hanafi Houoiten, and Ikhlass El Berbri analyzed the data and wrote the manuscript in French. Ikhlass El Berbri translated the manuscript to English. Ikhlass El Berbri and Badaoui Bouabid performed the statistical analysis.

\section{Acknowledgments}

The research leading to these results has received funding from the Virology laboratory of the Microbiology, Immunology and Infectious Diseases Unit of the Agronomic and Veterinary Institute Hassan II.

\section{Ethical consideration}

The authors declare that this manuscript is original, has not been published before and is not currently being considered for publication elsewhere.The manuscript reflects the authors' own research and analysis in a truthful and complete manner. All authors have been involved in substantial work leading to the manuscript. There are no other persons who satisfied the criteria for authorship but are not listed.

\section{REFERENCES}

Abutarbush SM (2014). West Nile Virus infection in horses in Jordan : Clinical cases, seroprevalence and risk factors. Transboundary and Emerging Diseases, 61: 1-6. DOI: https://www.doi.org/10.1111/tbed.1219.

Assaid N, Mousson L, Moutailler S, Arich S, Akarid K, Monier M, Beck C, Lecollinet S, Failloux AB, and Sarih MH (2020). Evidence of circulation of West Nile virus in Culex pipiens mosquitoes and horses in Morocco. Acta Tropica, 205: 105414. DOI: https://www.doi.org/10.1016/j.actatropica.2020.105414

Autorino GL, Battisti A, Deubel V, Ferrari G, Forletta R, Giovannini A, Lelli R, Murri S, and Scicluna MT (2002). West Nile virus epidemic in horses, Tuscany region, Italy. Emerging Infectious Disease, 8: 1372-1378. DOI: https://www.doi.org/10.3201/eid0812.020234

Baba SS, NNnadi OD, Hamman KD, Saidu A, Yuguda A, and El Oderinde BS (2014). Preliminary study on the prevalence of west nile virus antibody among horses, donkeys and camels in Borno State, Nigeria. Journal of Applied Virology, 3: 39. DOI: https://www.doi.org/10.21092/jav.v3i2.43

Bauerfeind R, Von Graevenitz A, Kimmig P, Schiefer HG, Schwarz T, Slenczka W, and Zahner H (2016). Zoonoses: Infectious diseases transmissible from animals and humans. Fourth edition. Washington, p. 544. DOI: https://www.doi.org/10.1128/9781555819262

Bażanów B, Jansen van Vuren P, Szymański P, Stygar D, Frącka A, Twardoń J, Kozdrowski R, and Pawęska JT (2018). A survey on West Nile and Usutu viruses in horses and birds in Poland. Viruses, 10: 12-14. DOI: https://www.doi.org/10.3390/v10020087

Beasley DWC, Whiteman MC, Zhang S, Huang CY, Schneider BS, Smith DR, Gromowski GD, Higgs S, Kinney RM et al. (2005). Envelope protein glycosylation status influences mouse neuroinvasion phenotype of genetic lineage 1 West Nile Virus strains. Journal of Virology, 79: 8339-8347. DOI: https://www.doi.org/10.1128/JVI.79.13.8339

Ben Hassine T, De Massis F, Calistri P, Savini G, BelHaj Mohamed B, Ranen A, Di Gennaro A, Sghaier S, and Hammami S (2014). First detection of co-circulation of West Nile and Usutu viruses in equids in the south-west of Tunisia. Transboundary and Emerging Diseases, 61: 385-389. DOI: https://www.doi.org/10.1111/tbed.12259

Benjelloun A, Harrak M, El Calistri P, Loutfi C, Kabbaj H, Conte A, Ippoliti C, Danzetta ML, Belkadi B et al. (2017). Seroprevalence of West Nile virus in horses in different Moroccan regions. Veterinary Medicine and Science, 3: 198-207. DOI: https://www.doi.org/10.1002/vms3.71

Calzolari M, Bonilauri P, Bellini R, Albieri A, Defilippo F, Galletti G, Gelati, Barbieri I, Tamba M et al. (2010). Evidence of simultaneous circulation of West Nile and Usutu viruses in mosquitoes sampled in Emilia-Romagna region (Italy) in 2009. PLoS One, 5: 1-10. DOI : https://www.doi.org/10.1371/journal.pone.0014324

Campbell GL, Marfin AA, Lanciotti RS, Gubler DJ, and Nile W (2002). Reviews West Nile virus. Lancet Infectious Diseases, 2: 519 529. DOI: https://www.doi.org/10.1016/s1473-3099(02)00368-7.

Cardinale E, Bernard C, Lecollinet S, Rakotoharinome VM, Ravaomanana J, Roger M, Olive MM, Meenowa D, Jaumally MR, J Melanie et al. (2017). West Nile virus infection in horses, Indian ocean. Comparative Immunology, Microbiology and Infectious Diseases, 53: 45-49. DOI: https://www.doi.org/10.1016/j.cimid.2017.06.006

Centers for Disease Control and Prevention (CDC) (2018). Symptoms, diagnosis, and treatment. West Nile Virus. Available at: https://www.cdc.gov/westnile/symptoms/index.html

Chemsi K (2019). Filière équine. LesEco.ma. Available at: https://leseco.ma/business/filiere-equine-l-ecosysteme-se-developpe-agrande-vitesse.html

Durand B, Chevalier V, Pouillot R, Labie J, Marendat I, Murgue B, Zeller H, and Zientara S (2002). West Nile Virus Outbreak in Horses, Southern France, 2000: Results of a Serosurvey. Emerging Infectious Diseases, 8: 777-782. Available at: https://wwwnc.cdc.gov/eid/article/8/8/01-0486_article

Durand B, Haskouri H, Lowenski S, Vachiery N, and Beck C (2016). Seroprevalence of West Nile and Usutu viruses in military working horses and dogs, Morocco, 2012: Dog as an alternative WNV sentinel species? Epidemiology and Infection, 144: 18571864. DOI: https://www.doi.org/10.1017/S095026881600011X

El Harrack M, Guenno B, and Le Gounon P (1997). Isolement du virus West Nile au Maroc. Virologie, 1: 248-249. 
El Rhaffouli H, El Harrak M, Lotfi C, El Boukhrissi F, Bajjou T, Laraqui A, Hilali F, Kenfaoui M, and Lahlou-Amine I (2012). Serologic evidence of West Nile Virus infection among humans, Morocco. Emerging Infectious Diseases, 18: 880-881. DOI: https://www.doi.org/10.3201/eid1805.110826

Figuerola J, Baouab RE, Soriguer R, Fassi-fihri O, Llorente F, and Jímenez-clavero MA (2009). West Nile Virus antibodies in wild. Emerging Infectious Diseases, 15: 2008-2010. DOI: https://www.doi.org/10.3201/eid1510.090340

Fujita DM, Salvador FS, Henrique L, Medicina I, De São T, De Laboratório P, Usp DP, Paulo S, and Amaro DS (2018). Letter to the editor the silent spread of West Nile virus in Brazil: Non-human positive case in a beach tourist destination - Espirito Santo. Journal of Travel Medicine, 25: 1-2. DOI: https://www.doi.org/10.1093/jtm/tay052

García-Bocanegra I, Jaén-Téllez JA, Napp S, Arenas-Montes A, Fernández-Morente M, Fernández-Molera V, and Arenas A (2012). Monitoring of the West Nile Virus epidemic in Spain between 2010 and 2011. Transboundary and Emerging Diseases, 59: 448455. DOI: https://www.doi.org/10.1111/j.1865-1682.2011.01298.x

Guerrero-Carvajal F, Bravo-Barriga D, Martín-Cuervo M, Aguilera-Sepúlveda P, Ferraguti M, Jiménez-Clavero MA, Llorente F, Alonso JM, and Frontera E (2020). Serological evidence of co-circulation of West Nile and Usutu viruses in equids from western Spain. Transboundary and Emerging Diseases, 68: 1-13. DOI: https://www.doi.org/10.1111/tbed.13810

Habarugira G, Suen WW, Hobson-Peters J, Hall RA, and Bielefeldt-Ohmann H (2020). West nile virus: An update on pathobiology, epidemiology, diagnostics, control and "One health" implications. Pathogens, 9: 1-51. DOI: https://www.doi.org/10.3390/pathogens9070589

Lafri I, Prat CM, Bitam I, Gravier P, and Besbaci M (2017). Seroprevalence of West Nile virus antibodies in equids in the North-East of Algeria and detection of virus circulation in 2014. Comparative Immunology, Microbiology and Infectious Diseases, 50: 8-12. DOI: https://www.doi.org/10.1016/j.cimid.2016.11.005

Lockaby G, Noori N, Morse W, Zipperer W, Kalin L, Governo R, Sawant R, and Ricker M (2016). Climatic, ecological, and socioeconomic factors associated with West Nile virus incidence in Atlanta, Georgia, U.S.A. Journal of Vector Ecology, 41: 232 243. DOI: https://www.doi.org/10.1111/jvec.12218

McLean RG, Ubico SR., Bourne D, and Komar N (2002). West Nile virus in livestock and wildlife. Current Topics in Microbiology and Immunology, 267: 271-308. DOI: https://www.doi.org/10.1007/978-3-642-59403-8_14

Murray KO, Mertens E, and Dspre PD (2010). West Nile virus and its emergence in the United States of America. Veterinary Research, 41: 67. DOI: https://www.doi.org/10.1051/vetres/2010039

Nall R (2018). West Nile Virus: Symptoms, Causes, and Treatment. Healthline. Available at: https://www.healthline.com/health/westnile-virus.

World Organisation for Animal Health (OIE) (2018). Chapter 3.1.24 West Nile Fever. OIE-Terrestial Manual. Available at: https://www.oie.int/fileadmin/Home/fr/Health_standards/tahm/F_summry.htm

World Organisation for Animal Health (OIE) (2021). West Nile fever- World Organisation for Animal Health. Available at: https://www.oie.int/en/animal-health-in-the-world/animal-diseases/west-nile-fever

Ostlund EN, Crom RL, Pedersen DD, Johnson DJ, Williams WO, and Schmitt BJ (2001). Equine West Nile encephalitis, United States. Emerging Infectious Diseases, 7: 665-669. DOI: https://www.doi.org/10.3201/eid0704.017412

Ramakrishnan MA (2016). Determination of 50\% endpoint titer using a simple formula. World J Virol 2016; 5(2): 85-86. DOI: http://www.dx.doi.org/10.5501/wjv.v5.i2.8

Reed LJ, Muench H (1938). A simple method of estimating fifty percent endpoints. The American Journal of Hygiene, $27: 493-497$.

Reiter P (2010). West Nile virus in Europe: Understanding the present to gauge the future. Eurosurveillance, 15: 4-10. DOI: https://www.doi.org/10.2807/ese.15.10.19508-en.

Samuel MA, and Diamond MS (2006). Pathogenesis of West Nile virus infection : A Balance between Virulence, Innate and Adaptive Immunity, and Viral Evasion. Journal of Virology, 80: 9349-9360. DOI: https://www.doi.org/10.1128/JVI.01122-06

Schuffenecker I, Peyrefitte CN, Harrak M, Murri S, Leblond A, and Zeller HG (2005). West Nile virus in Morocco, 2003. Emerging Infectious Diseases, 11: 2003-2006. DOI: https://www.doi.org/10.3201/eid1102.040817

Tber A (1996). West Nile fever in horses in Morocco. Bulletin de l'Office international des épizooties, 11 : 867-869.

Vanhomwegen J, Beck C, Desprès P, Figuerola A, García R, Lecollinet S, López-Roig M, Manuguerra JC, and Serra-Cobo J (2017). Circulation of zoonotic arboviruses in equine populations of Mallorca Island (Spain). Vector-Borne Zoonotic Diseases, 17: 340346. DOI: https://www.doi.org/10.1089/vbz.2016.2042

World Health Organization (WHO) (2017). West Nile Virus. World Health Organization. Available at: https://www.who.int/newsroom/fact-sheets/detail/west-nile-virus 